\title{
The Water-energy Nexus in the Island of Crete, Greece
}

\author{
John Vourdoubas \\ Consultant Engineer, 107B, El. Venizelou str., Chania, Crete, Greece \\ E-mail: vourhome@otenet.gr
}

Received: March 9, 2021 Accepted: April 3, 2021 Published: April 8, 2021

doi:10.5296/emsd.v10i2.18504 URL: https://doi.org/10.5296/emsd.v10i2.18504

\begin{abstract}
Water and energy are valuable resources in our contemporary societies. Their demand worldwide is increasing while they are interconnected and interlinked. Aim of the current work is to investigate the nexus between water and energy in the island of Crete, Greece. The use of water in electricity generation and in fuels production is investigated as well as the electricity utilization in water pumping, transportation, processing and distribution. Our results indicated that the annual electricity consumption in Crete is at $4,793 \mathrm{KWh} /$ capita while the annual water consumption is at around $763.9 \mathrm{M}^{3} /$ capita to $962.2 \mathrm{M}^{3} /$ capita. The main fuels used in electricity generation in Crete are fuel oil and diesel oil that are imported. Among renewable energies solar-PV and wind energy are mainly used for power generation. Generation of solar-PV and wind electricity requires limited water resources while in water-cooled thermal power stations brackish and desalinated water is mainly used. Crete has sufficient water resources which though are unevenly distributed along the island. Groundwater is the main water source used while agriculture is the main sector of water consumption. Electricity is necessary in all stages of water utilization in Crete. The results indicated that the nexus between water and energy in Crete is asymmetrical and uneven. Electricity generation is not significantly depended on freshwater resources while water utilization is depended on electricity. These findings could be useful in designing the optimum management policies regarding the long term sustainability of these valuable resources in Crete.
\end{abstract}

Keywords: Crete-Greece, Electricity, Energy, Water-energy nexus, Renewable energies, Resources, Water

\section{Introduction}

Water and energy are basic resources in our societies. Demand in both of them is increasing due to increase in global population and in economic growth. Climate change undermines the security and availability of water and energy systems particularly in fragile areas with limited resources. Island of Crete, Greece is a popular tourist destination in eastern Mediterranean 
region with a constantly growing tourism industry. Energy and water resources are very important for the sustainability and prosperity in tourism dominated societies. Tourism industry in Crete contributes approximately at $48 \%$ in the regional domestic product while it is very important in island's prosperity. European policies require the de-carbonization of the continental energy system in the next 30 years combined with the water resources sustainability. Water and energy are interlinked and interwoven since water is required in fuels and energy production while energy is required in water production and utilization. The links and the nexus between water and energy in Crete are examined in order to design better management policies improving their long term sustainability.

\section{Literature Survey}

\subsection{The Water-energy Nexus}

Endo et al, 2017 have studied the current research regarding the water, energy and food nexus. The authors reviewed 37 projects identifying four types of nexus research including water-food, water-energy-food, water-energy and climate related. They stated that 12 projects were related to water-energy, 11 to water-food-energy, 6 to water-food while the remaining 8 projects were climate related. Hussy et al, 2012 have investigated the links between energy and water for a sustainable future. The authors stated that when water and energy rely on each other then complex challenges are posed for policy makers. They also mentioned that both water and energy are indispensable inputs to modern economies while their sectors have undergone rapid transformation. $\mathrm{Li}, 2014$ has studied the water-energy nexus in Ningxia, China. The author mentioned that Ningxia is extremely scarce in water resources but abundant in coal. He stated that water supply could not meet the overall demand while the energy sector would be growing very fast if water was abundant. Tan et al, 2016 have studied the water-energy nexus focusing on the dependence of energy on water. The authors stated that the demand of both resources is expected to grow with the increasing population and economic growth. They mentioned that primary energy resources as well as electricity generation depend on water. A report on the water-energy nexus in Europe has been published, 2019. The report mentioned that energy and water are interlinked. Water is required in energy generation, cooling and storage as well as for biomass and bio-fuels production. Energy is required in water pumping, processing and desalination. However despite of their synergies there is a lack in policy integration among water, energy and climate change mitigation. Wang, 2017 has studied the water-energy nexus. The author stated that the interdependency between two critical resources like water and energy is recently receiving attention. Better understanding of their synergies and linkages is necessary for achieving sustainable resource management. Solaum et al, 2017 have studied the impact of climate change on electricity generation in southern Spain. The authors analyzed the long-term impacts of changes in precipitation and water availability on hydroelectricity generation with reference three hydroelectric power plants located in southern Spain. They stated that a drop in hydroelectricity generation between $10 \%$ and $49 \%$ by the end of the century is foreseen. Spang et al, 2014 have studied the water consumption in energy generation. The authors estimated that approximately 52 bil. $\mathrm{M}^{3}$ of fresh water are consumed annually in global energy production. They also stated that approximately three quarters of the water is 
consumed in fuels production and only one quarter in electricity generation. Water usage in electricity generation by renewable energies, without taking into account the water use in hydroelectricity production, corresponds only at $1.5 \%$ of the total annual water consumption attributed to fuels production and electricity generation. Richter et al, 2009 have investigated methods for reducing the cooling water consumption in solar thermal power plants. The authors stated that the use of direct and indirect dry cooling can eliminate over $90 \%$ of the water consumed in a water-cooled concentrated solar power plant. The drawback of this cooling option is a small increase in the cost of electricity generation. Larsen et al, 2019 have analyzed the water-energy nexus in electricity generation. The authors stated that there is a gap in the availability and quality of proper regional and global data for assessing the water-energy nexus. They highlighted the water usage rates in electricity generation with different technologies with potential to reduce water usage. Deane et al, 2010 have reviewed the technical and economic characteristics of pumped hydro energy storage plants. The authors mentioned that there is an increasing interest for hydro electricity storage systems due to development of electricity generation from intermittent renewable energies. They stated that Europe is the leading area for the development of these systems while their capital cost varies between $€ 470 / \mathrm{KW}$ and $€ 2,170 / \mathrm{KW}$ depending on the site and the project. Gutierrez-Martin et al, 2020 have investigated the production of $\mathrm{H}_{2}$ by water electrolysis and off-grid solar photovoltaic (solar-PV) systems with reference Madrid, Spain and Fisciano, Italy. The authors experimented with $\mathrm{H}_{2}$ generation in off-grid locations in which solar-PV electricity was continuously injected into an electrolytic cell or in batteries. They mentioned that the cost of $\mathrm{H}_{2}$ produced was at around 6-7 $€ / \mathrm{KWh}$. Kovac et al, 2019 have investigated the solar $\mathrm{H}_{2}$ production via alkaline water electrolysis using a $960 \mathrm{~W}_{\mathrm{p}}$ solar-PV system. The authors stated that the annual electricity generation was estimated at 1,234 $\mathrm{KWh}$ while the calculated hourly $\mathrm{H}_{2}$ production rate was at $1.14 \mathrm{grH}_{2}$. Zoulias et al, 2004 have reviewed the $\mathrm{H}_{2}$ production with water electrolysis. The authors stated that water electrolysis is considered as the "cleanest" way to produce $\mathrm{H}_{2}$ when the required electricity is derived from renewable energies. They also mentioned that production of $1 \mathrm{M}^{3}$ of $\mathrm{H}_{2}$ requires 4-5 KWh of electricity. Argaw, 2003 has studied the use of renewable energies in water and wastewater treatment plants. The authors stated that various renewable energies including solar energy, wind energy and biogas have increasing use in water and wastewater treatment plants. He also mentioned that solar energy is used in disinfection, desalination as well as in heat and electricity generation in these plants. Shen et al, 2015 have overviewed the biogas production and utilization in wastewater treatment plants (WWTPs) in USA. The authors stated that less than $10 \%$ of the WWTPs in USA are currently producing biogas for beneficial use. They mentioned that co-digestion of bio-solids with organic wastes could be an attractive option in existing digesters increasing biogas production in WWTPs. Natale et al, 2013 have studied the use of a solar pumping system for irrigation of horticulture in India. The authors stated that the solar-PV system was capable of irrigating 0.165 ha of banana plot with daily water requirements at $9.72 \mathrm{M}^{3}$ and total head at $26 \mathrm{~m}$. They also mentioned that the positive cost analysis encouraged the use of solar-PV systems in water pumping and in irrigation of orchards. Shinde et al, 2015 have reviewed the use of solar-PV systems in water pumping and irrigation in India. The authors stated that the use of solar-PV irrigation systems is valuable in 
areas without electric grids. They mentioned that solar-PV pumps at $1 \mathrm{KW}_{\mathrm{p}}$ are economic for irrigation while at $3 \mathrm{KW}_{\mathrm{p}}$ for water supply in villages. Delgado et al, 2012 have developed a simple model for better understanding of water usage in power plants. The authors stated that the interdependency between water and energy is investigated carefully due to the increasing demand in both resources. They mentioned that in USA thermal power plants account for $40 \%$ of the total fresh water withdrawals every year. Rodriguez et al, 2013 have studied the interdependencies and trade-offs between water and energy. The authors stated that both population growth and economic growth are expected to increase the demand for food, energy and water while water scarcity is increasing. They also mentioned that climate change is exacerbating energy and water insecurity due to extreme weather conditions and events. Abdelkareem et al, 2017 have reviewed the recent progress in the use of renewable energy sources to power water desalination plants. The authors stated that various renewable energy technologies can power the energy intensive water desalination plants. They mentioned that solar thermal systems, solar-PV systems, concentrated solar thermal power systems and wind turbines are already used in these plants while the use of additional benign energy technologies is in the development phase. Fernadez-Gil et al, 2019 have studied the sustainable water generation in the small Greek island Skyros with autonomous electric grid and limited water resources. The authors proposed a water production system to cover the potable and irrigation needs in the island. Potable water was produced in desalination units while irrigation water was provided by the treated sewage effluents. All the energy needs during water production were covered with renewable energies. They stated that the total water production cost was estimated at $2.49 € / \mathrm{m}^{2}$ that is significantly lower than the current cost of imported water in the island. Calise et al, 2020 have studied the use of polygeneration systems producing water and energy in two small Mediterranean islands. The authors mentioned that solar energy and seawater are abundant in these islands while freshwater is scarce. They stated that in small and isolated Mediterranean islands with lack of fossil fuels and freshwater the use of various polygeneration systems using locally available renewable energies and seawater could provide the required heat, electricity and freshwater at an affordable cost. The published research indicates that global demand in water and energy is growing while both resources are interlinked and interdepended. Water is needed in fuels production and energy generation while energy is required during water production, processing and distribution. Climate change mitigation requires a radical energy transition to a low carbon energy system while climate change influences the availability of freshwater resources.

\subsection{The Energy System in Crete}

Electricity generation and fossil fuel consumption in Crete in 2018 has been reported by DEDDIE, 2018. Total electricity generation in Crete during 2018 was at 3,042,549 MWh while most of it was generated in thermal power stations fueled by heating oil and diesel oil. The share of renewable energies (REs) in electricity generation was slightly higher than $20 \%$. Vourdoubas, 2020 has reviewed the use of REs for energy generation in rural areas in the island of Crete, Greece. The author stated that solar energy, wind energy, hydro power, biomass and low enthalpy geothermal energy are already used in Crete for heat and power 
production. He also mentioned that REs currently generate more than $20 \%$ of the total annual electricity consumption in the island. Katsaprakakis et al, 2019 have studied the transition of Crete into an energy independent island. The authors stated that fossil fuels can be replaced in electricity generation with renewable energies which are abundant in Crete. Despite though the forthcoming Crete's interconnection with the Greek mainland grid, they mentioned, high penetration of renewable energies can be only achieved with the construction of pump hydro electricity storage systems. Nikolaou et al., 2020 have estimated the characteristics of a pumped hydro energy storage system in Crete. The authors investigated the possibility of using the existing "Potamon" dam located in central Crete with appropriate modifications for storing the rejected wind electricity in the island. They mentioned that the amount of electricity that can be stored in the existing dam is approximately at 70,000 MWh/year corresponding at around $2 \%$ of the island annual electricity consumption while the annual carbon emission savings were estimated at around 50,000 tonCO $\mathrm{CO}_{2}$. Vourdoubas, 2018 has studied the creation of zero carbon emissions wastewater treatment plants due to energy use with reference the island of Crete, Greece. The author stated that installation of solar-PV systems and wind turbines could generate part of plant's electricity requirements. Additional electricity could be generated from the biogas produced during sludge's digestion in the plant.

\subsection{Water Resources in Crete}

Baltas et al, 2013 have studied the management of water resources in the island of Crete, Greece. The authors stated that Crete has limited water resources and growing water demands. They mentioned that stakeholder's engagement in all stages of the management plan creation facilitates the cooperation among various authorities and water end users. They also stated that the mean annual precipitation in various locations in the island varies between $327 \mathrm{~mm}$ and 2,161 mm. Tzanakakis et al, 2020 have studied the challenges and opportunities for sustainable management of water resources in the island of Crete, Greece. The authors stated that under average meteorological conditions, with mean annual precipitation at $969 \mathrm{~mm}$, the island is self-sufficient in water resources. They mentioned that agriculture is by far the greatest user of water with a share at $78 \%$ in total water use followed by domestic use at $21 \%$. However despite the high average water availability water scarcity events commonly occur particularly in the eastern-south part of the island due to various water management deficiencies. Tsagarakis et al, 2004 have investigated the possibility of wastewater recycling and reuse in agriculture in the island of Crete. The authors stated that despite of the adequate annual precipitation in Crete water shortages are experienced due to spatial variations in precipitation rate, the increase in water demand during the summer and the difficulties in transporting water resources in long distances. They mentioned that there is a high potential for wastewater recycling and reuse in irrigation resulting in water saving of up to $5 \%$ of the total irrigation water. Chartzoulakis et al, 2001 have studied the water resources management in the island of Crete, Greece. The authors stated that the average annual precipitation rate was estimated at $900 \mathrm{~mm}$ the potential annual water availability at 2,65 mil. $\mathrm{M}^{3}$ while the real water consumption at 485 mil. $\mathrm{M}^{3}$. They also mentioned that the share of agriculture in the overall water consumption was at $84.5 \%$, of domestic use at $12 \%$ while of other uses at $3.5 \%$. Kourgialas et al, 2018 have developed a methodology for estimating groundwater's footprint 


\section{Macrothink}

with reference the island of Crete, Greece. The authors mentioned that the main water supply in Crete is groundwater. They also stated that the majority of aquifers studied in Crete have indicated low stress.

Aims of the current research are:

a) The study of the energy system in Crete,

b) The study of water resources in Crete, and

c) The study of their interdependencies and synergies.

Initially the existing literature is reviewed followed by the study of the island's energy system and the required water resources in energy generation and fuels production. After that the water system in Crete is stated combined with the energy required for water pumping, transportation, processing and distribution. Next the synergies between water resources and energy in Crete are discussed followed by conclusions drawn and proposals for further research.

\section{The Energy System in Crete}

Energy and fuels are produced in Crete with a mix of technologies using both fossil fuels and renewable energies. Fossil fuels are not produced in the island but they are imported. They are used in heat production, electricity generation and in vehicle's transportation. Locally available REs are also used in Crete for heat and electricity generation including solar energy, wind energy, hydro power as well as solid and gaseous biomass. The main fuels currently used in energy generation in Crete are presented in table 1 while the size of the electricity generation plants in Crete is presented in table 2.

Table 1. Fossil fuels and renewable energies currently used for energy generation in Crete, Greece

\begin{tabular}{|l|l|l|l|}
\hline Energy generated & Fuel/energy source & $\begin{array}{l}\text { Type of } \\
\text { fuel/energy source }\end{array}$ & $\begin{array}{l}\text { Is the fuel or the energy source } \\
\text { locally produced or available? }\end{array}$ \\
\hline Electricity & Fuel oil, diesel oil & Fossil fuels & No \\
\hline Electricity & $\begin{array}{l}\text { Solar-PV, wind energy, } \\
\text { hydro energy, biogas }\end{array}$ & Renewable energies & Yes \\
\hline Heat & Fuel oil, diesel oil, LPG & Fossil fuels & No \\
\hline Heat & $\begin{array}{l}\text { Solar thermal, solid } \\
\text { biomass, ambient heat }\end{array}$ & Renewable energies & Yes \\
\hline $\begin{array}{l}\text { Mechanical energy in } \\
\text { vehicle's transportation }\end{array}$ & Diesel oil, Gasoline, LPG & Fossil fuels & No \\
\hline
\end{tabular}

Note. Own estimations 
Table 2. Size of the electricity generation plants in Crete

\begin{tabular}{|l|l|l|l|}
\hline Fuel/energy source/technology & Installed power (MW) & Electricity generated (MWh) & $\%$ \\
\hline Thermal power stations using fuel oil & 620.3 & $1,762,612$ & 57.94 \\
\hline Thermal power stations using diesel oil & 204.3 & 635,070 & 20.87 \\
Wind parks & 200.3 & 510,059 & 16.76 \\
Solar-PV systems & 95.5 & 134,808 & 4.43 \\
Hydro electric plants & 0.6 & - & - \\
Biogas using plants & $<1$ & - & - \\
Total & 1025.5 & $3,042,549$ & 100 \\
\hline
\end{tabular}

Note. Annual report on the energy system in Crete, 2018, Own estimations

Electricity storage in large scale hydro pump storage systems is foreseen in the future. Current advances in electric battery's technologies could also allow electricity storage in large scale electric batteries in the near future. Its storage in electrolytic hydrogen in not predicted soon. Crete is rich in solar and wind energy resources while two micro hydro electric plants operate in the west part in the island. Solid biomass resources are also abundant in Crete based on the broad cultivation of olive trees. Tree's by-products and residues are currently used for heat generation in buildings, industry and in agriculture. The interconnection of the island's electric grid with the grid in continental Greece, which is currently under construction, is going to decrease the generation of electricity in the existing local thermal power stations. The interconnection of the two electric grids will allow the transfer of electricity between Crete and continental Greece while it is expected to increase the generation of electricity from the abundant solar and wind energy resources in the island. It is also foreseen in the future that one or two solar thermal power stations will be constructed in Crete while hydro pump storage systems are going to be created increasing the energy security in the island.Taking into account that the electricity generation in Crete in 2018 was at 3,043 GWh (Annual report on the energy system in Crete, 2018) while the permanent residents in the island are 634,930 the electricity generation in Crete is estimated at $4,793 \mathrm{KWh} /$ capita while the amount generated by renewable energies is at 1,017 $\mathrm{KWh}$ /capita. The electric grid in Crete in 2018 was autonomous without any electricity storage. Therefore the electricity consumption per capita was similar with the electricity generation per capita.

\section{Water Resources in Crete}

Water is a valuable resource in modern societies. Island of Crete is characterized by uneven water availability in the eastern and western part of it. Although, due to satisfactory average annual precipitation at $969 \mathrm{~mm}$, the island is self-sufficient in water resources the eastern part of Crete is dryer than the west having significant lower annual precipitation rates. This results in water scarcity in some areas. The geomorphology of the island and the insufficient management of the existing water resources result in inadequate water availability.The water resources currently used in Crete are conventional and non-conventional. Conventional resources include surface and underground water. Non-conventional resources comprise water recycled and reused, brackish water and desalinated water. During the last years the 


\section{Ml Macrothink}

first two water desalination plants have been constructed in eastern Crete. More than $75 \%$ of the water resources in Crete are currently used in agriculture where the water saving potential is high. It has been reported that $93 \%$ of water used in agriculture is underground water (Tzanakakis et al, 2020). Development of precision agriculture and improvements in irrigation technology are expected to reduce future water demand in food production in Crete. However growth of tourism is increasing since the island is a popular tourist destination attracting more tourists every year. The thriving tourism industry is going to increase the future water demand. Climate change is foreseen to reduce water availability in Crete lowering the annual precipitation rate. Therefore in order to avoid future water scarcity in Crete it is necessary to create better water management policies. The inter-linkages and interdependencies among water-energy-food and climate change in Crete should be better studied and understood for developing the optimum management policies and avoiding future water and energy shortages. The annual water consumption in Crete has been estimated between $763.9 \mathrm{M}^{3} /$ capita and $962.2 \mathrm{M}^{3} /$ capita. Utilization of water resources in various sectors in Crete is presented in tables 3 and 4. The differences in the utilization of water resources in Crete in the following tables are due to estimations at different years by different authors.

Table 3. Utilization of water resources in Crete

\begin{tabular}{|l|l|l|l|}
\hline Sector & $\begin{array}{l}\text { Annual water } \\
\text { consumption }(\%)\end{array}$ & $\begin{array}{l}\text { Annual water } \\
\text { consumption }\left(\mathrm{mil}^{3} \mathrm{M}^{3}\right)\end{array}$ & $\begin{array}{l}\text { Annual water consumption } \\
\text { per capita( } \mathrm{M}^{3} \text { per capita) }\end{array}$ \\
\hline Agriculture & 84.5 & 409.8 & 645.4 \\
\hline Domestic & 12 & 58.2 & 91.7 \\
Other & 3.5 & 17.0 & 26.8 \\
Total & 100 & 485 & 763.9 \\
\hline
\end{tabular}

Note.Chartzoulakis et al, 2001, Permanent residents in Crete: 634,930

Table 4. Utilization of water resources in Crete

\begin{tabular}{|l|l|l|l|}
\hline Sector & $\begin{array}{l}\text { Annual water } \\
\text { consumption }(\%)\end{array}$ & $\begin{array}{l}\text { Annual water } \\
\text { consumption }\left(\mathrm{mil}^{\mathrm{M}} \mathrm{M}^{3}\right)\end{array}$ & $\begin{array}{l}\text { Annual water consumption } \\
\text { per capita( } \mathrm{M}^{3} \text { per capita) }\end{array}$ \\
\hline Agriculture & 78.3 & 478.4 & 753.5 \\
\hline Domestic & 20.9 & 127.6 & 201.0 \\
Other & 0.80 & 4.9 & 7.7 \\
Total & 100 & 610.9 & 962.2 \\
\hline
\end{tabular}

Note.Tzanakakis et al, 2020, Permanent residents in Crete: 634,930

\section{Water Utilization in Energy Generation and Fuels Production in Crete}

Electricity is currently generated by fossil fuels and renewable energies in Crete. The existing thermal power stations are fueled with fuel oil and diesel oil. Some of them are water-cooled while others are air-cooled. In the water-cooled thermal power stations brackish and sea water is mainly used while the use of valuable fresh water resources is avoided. Renewable energies including solar-PV energy, wind energy, hydro energy and biogas are also used in 
electricity generation. Around $99 \%$ of the current annual "green electricity" in the island is generated by solar-PV systems and wind parks which require negligible amounts of water during their operation. Solar-PV systems require water for washing the panels. Biogas production via digestion needs small amounts of water while wastewater in the two sewage treatment plants in Crete is used for its production. Two micro hydro power stations located in western Crete have almost zero impacts in water consumption. Small quantities of water are also needed in washing the solar panels used in domestic hot water production in the island. The fossil fuels used in energy generation in Crete are not locally produced. The only fuel produced in large quantities is solid biomass which is based in residues, by-products and wastes of olive trees which are cultivated extensively in Crete. Olive tree orchards require irrigation water which though is attributed to olive oil production. Future increase in electricity generation from solar-PV systems and wind parks in Crete is not going to increase significantly the utilization of fresh water resources. Installation of water-cooled solar thermal power plants in Crete could probably require water resources. Creation of electricity storage systems based in pump hydro storage in Crete requires water resources which though are not consumed. However small quantities of water are expected to evaporate from the water basins constructed in these energy storage systems. The pump hydro electricity storage system in "Potamon" dam has a guarantee power capacity at $50 \mathrm{MW}$ while it is expected to generate $227 \mathrm{GWh}$ annually (Tzanakakis et al, 2020). Water uses related with energy generation and fuels production in Crete are presented in table 5.

Table 5. Water uses related with energy generation and fuels production in Crete

\begin{tabular}{|l|l|}
\hline $\begin{array}{l}\text { Energy generation and } \\
\text { fuels production }\end{array}$ & Water requirements \\
\hline $\begin{array}{l}\text { Electricity generation by fuel oil } \\
\text { and heating oil }\end{array}$ & $\begin{array}{l}\text { Cooling water is required in water-cooled thermal power } \\
\text { stations. Brackish and desalinated water are mainly used. }\end{array}$ \\
\hline Solar-PV electricity & Small water quantities are required for washing the solar panels \\
\hline Wind electricity & Negligible water quantities are required \\
\hline Hydro electricity & Two tiny hydro power stations are using small water quantities \\
\hline Electricity generated from biogas & Small water quantities are required \\
\hline Biogas production & Biogas production requires small water quantities \\
\hline Solid biomass production & $\begin{array}{l}\text { Solid biomass generated mainly by olive trees requires irrigation } \\
\text { water which is attributed to olives and olive oil production. }\end{array}$ \\
\hline $\begin{array}{l}\text { Domestic hot water production } \\
\text { with solar thermal systems }\end{array}$ & Small quantities of water are required for washing the solar panels \\
\hline Solar thermal electricity & Water is required in the case of water-cooled solar thermal power plants \\
\hline $\begin{array}{l}\text { Electricity storage in pump } \\
\text { hydro storage systems }\end{array}$ & $\begin{array}{l}\text { Water is required but it is not used. Water though is evaporated } \\
\text { in water basins. }\end{array}$ \\
\hline
\end{tabular}

Note. Own estimations

\section{Energy Utilization in Water Production, Transportation, Processing, Distributionand use in Crete}

Electricity is required in all stages of water production, transportation, processing, distribution and utilization in Crete. Since underground water is the main water source used in Crete, electricity is required for its pumping and transportation at the consumption sites 
along the island. Solar-PV systems have been installed in some water pumping stations in Crete generating on-site the required energy. Electricity is also needed in the municipal plants producing potable water as well as in the municipal sewage treatment plants. Recycling of grey water and use of brackish water requires the operation of electric equipment. Additionally electricity is needed in the desalination plants currently operating in Crete. Therefore electricity is a basic energy source involved in all stages of water utilization in the island while around $80 \%$ of it is generated by fossil fuels.

\section{Discussion}

Investigation of the linkages and interdependencies between water and energy is necessary for designing the optimum management policies for these valuable resources. Water is required in fuels production and in electricity generation in thermal power plants. Energy is required in water pumping, transportation, processing and distribution. Our results indicated that the relation between water and electricity in Crete is unequal. Water production and utilization is depended on electricity while electricity generation is less depended on water. On-site generated solar-PV electricity is partly used in water pumping. The future energy transition in Crete to a low carbon economy through the promotion of locally available renewable energies in electricity generation is going to decrease the dependence of energy generation on water availability. This is positive taking into account the impacts of climate change on water resources as well as the future increase in fresh water demand because of the flourishing tourism industry in the island. The rich solar and wind energy resources in Crete favor the decoupling of water pumping, processing and distribution on grid electricity that is mainly based on fossil fuels. Future interconnection of the electric grids of Crete and continental Greece will reduce the dependence of electricity generation on water resources. Our results differ from the results reported in other regions indicating a strong interrelation between water and energy. They indicated that future efforts in Crete should be focused in decreasing the dependence of water utilization on electricity.This could be achieved with improvements in water efficiency in agriculture as well as in the residential and the hospitality sector. Additionally "green solar and wind electricity" should be used on-site in water pumping, transportation, processing and distribution.

\section{Conclusions}

The nexus between water and energy in the island of Crete, Greece has been investigated. Electricity is currently generated in thermal power stations using liquid fossil fuels imported in the island while solar-PV and wind electricity contributes approximately at $20 \%$ in the total annual electricity generation. Total annual electricity consumption in Crete has been estimated at 4,793 KWh/capita while "solar and wind electricity" consumption has been estimated at 1,017 KWh/capita. Generation of solar-PV and wind electricity has negligible water requirements. Heat production in Crete has also low impacts in water resources utilization. The interconnection of the island's electric grid with the grid of continental Greece is under construction. It is expected that its finalization will reduce the use of imported fossil fuels in electricity generation in Crete while it will increase the generation of solar-PV and wind electricity. The majority of thermal power stations operating in Crete are 
air-cooled while the water-cooled stations are utilizing either brackish water or desalinated water. Therefore the use of fresh water in island's thermal power station is low. Water utilization in fuels production in the island is negligible. Crete has adequate water resources which though are unevenly distributed between the western and the eastern part in the island resulting in local water scarcity. Total annual water consumption in Crete has been estimated between $763.9 \mathrm{M}^{3}$ /capita (2001) and 962.2 $\mathrm{M}^{3}$ /capita (2020). During the period 2001-2020 the water consumption per capita has been increased as well as the percentage used in the domestic sector including tourism while the percentage of water resources used in agriculture has been decreased. The majority of water use in Crete is groundwater while more than $75 \%$ of it is used in crop's irrigation. Water pumping, transportation, processing and distribution require electricity. Therefore the relation between energy and water resources in Crete is uneven and asymmetrical. Electricity generation in Crete is not significantly depended on the availability of fresh water resources while water utilization is highly depended on the availability of electricity. Future water utilization in Crete should be decoupled from electricity consumption based on fossil fuels. This could be achieved with the use of solar-PV electricity in water pumping and transportation as well as with the use of renewable energy technologies in water desalination, water processing and in wastewater treatment plants. Future research should be focused on: a) Estimation of the electricity required in all stages of water utilization in the island, b) Estimation of the water required in electricity generation, and c) Minimization of electricity consumption based on fossil fuels in water pumping, transportation, processing and distribution exploiting the island's abundant renewable energy resources.

\section{References}

Abdelkareem, M.A., Haj Assad, M.El., TahaSayed, E., \& Soudan, B. (2017). Recent progress in the use of renewable energy sources to power water desalination plants. Desalination.https://doi.org/10.1016/j.desal.2017.11.018

Annual report on the energy system in Crete (Hellenic Electricity Distribution Network Operator, 2018) (in Greek).

Argaw, N. (2003, February 24). Renewable energy in water and wastewater treatment applications, National Renewable Energy Laboratory, USA, Department of Energy.[Online] Available: https://www.nrel.gov/docs/fy03osti/30383.pdf

Baltas, E., \&Tzoraki, O. (2013, March 5). Water resources management on the island of Crete: Lessons learnt. [Online] Available:

https://www.researchgate.net/publication/260293373_Water_resources_management_on_the _island_of_Crete_Lessons_learnt

Calise, F., LiberatoCappiello, F., Vicidomini, M., \&Petrakopoulou-Robinson, F. (2020). Water-energy nexus: A thermoeconomic analysis of polygeneration systems for small Mediterranean islands. Energy Conversion and Management,220, 113043.

https://doi.org/10.1016/j.enconman.2020.113043

Chartzoulakis, K.S., Paranychiakis, N.V., \&Angelakis, A.N. (2001).Water resources 
management in the island of Crete, Greece, with emphasis on the agricultural use.Water Policy, 3, 193-205. https://doi.org/10.1016/S1366-7017(01)00012-5

Deane, J.P., O’Gallachoir, B.P., \&McKeogh, E.J. (2010).Techno-economic review of existing and new pump hydro energy storage plant.Renewable and Sustainable Energy Reviews, 14, 1293-1302. https://doi.org/10.1016/j.rser.2009.11.015

Delgado, A., \& Herzog, H.J. (2012, February 26). A simple model to help understand water use at power plants, Massachusetts Institute of Technology, USA.[Online] Available: https://sequestration.mit.edu/pdf/2012_AD_HJH_WorkingPaperWaterUse_at_PowerPlants.pdf

Endo, A., Tsurita, I., Burnett, K., \&Orencio, P.M. (2017).A review of the current state of research on the water, energy and food nexus.Journal of Hydrology: Regional Studies, 11, 20-30. http://dx.doi.org/10.1016/j.ejrh.2015.11.010

Fernandez-Gil, G., \&Petrakopoulou, F. (2019).Sustainable water generation on a Mediterranean island in Greece.Energies, 12, 4247.https://doi.org/10.3390/en12224247

Gutierrez-Martin, F., Amodio, L., \& Pagano, M. (2020).Hydrogen production by water electrolysis and off-grid solar PV.International Journal of Hydrogen Energy.

https://doi.org/10.1016/j.ijhydene.2020.09.098

Hussey, K., \&Pittock, J. (2012). The Energy-Water Nexus: Managing the Links between Energy and Water for a Sustainable Future. Ecology and Society, 17(1), 31.

https://doi.org/10.5751/ES-04641-170131

Katsaprakakis, D., Antonakakis, I., Dakanali, I., \& Christakis, D. (2019).Turning Crete into an energy independent island. Paper presented at the 4th International Hybrid Power Systems workshop, Crete, Greece, 2019. [Online] Available:

https://www.researchgate.net/publication/333701601_Turning_Crete_into_an_energy_indepe ndent_island.

Kavac, A., Marcius, D., \&Budin, L. (2019).Solar hydrogen production via alkaline water electrolysis.International Journal of Hydrogen Energy, 44, 9841-9848.

https://doi.org/10.1016/j.ijhydene.2018.11.007

Kourgialas, N.N., Karatzas, G.P., Dokou, Z., \&Kokorogiannis, A. (2018). Groundwater footprint methodology as policy tool for balancing water needs (agriculture \& tourism) in water scarce islands - The case of Crete, Greece. Science of the Total Environment, 615,381-389. https://doi.org/10.1016/j.scitotenv.2017.09.308

Larsen, M.A.D., Petrovic, S., Engstrom, R.E., Drews, M., Liersch, S., Karlsson, K.B., \& Howells, M. (2019). Challenges of data availability: Analyzing the water-energy nexus in electricity generation. Energy Strategy Reviews, 26, 100426.

https://doi.org/10.1016/j.esr.2019.100426

Li, X. (2014, March 5). Understanding the water-energy nexus: A case study of Ningxia.Master Thesis in Sustainable Development at Uppsala University, No. 204, pp. 44.[Online]

Available: 
https://www.diva-portal.org/smash/get/diva2:747151/FULLTEXT01.pdf

Magagna, D., Hidalgo Gonzalez, I., Bidoglio, G.,\&Peteves, S. (Editors) (2019, February 24). Water-energy nexus in Europe.[Online] Available:

https://ec.europa.eu/jrc/en/publication/eur-scientific-and-technical-research-reports/water-ene rgy-nexus-europe

Natale, P.D., Rathore, N.S., \& Kothari, S. (2013). Study of solar PV water pumping system for irrigation of horticultural crops.International Journal of Engineering Science Invention, 2(12), 54-60. [Online] Available:

https://pdf4pro.com/view/study-of-solar-pv-water-pumping-system-for-irrigation-of-4ad2b0.h tml

Nikolaou, T., Stavrakakis, G.S., \&Tsamoudalis, K. (2020). Modeling and optimal dimensioning of a pumped hydro energy storage system for the exploitation of the rejected wind energy in the non-interconnected electrical power system of the Crete island, Greece. Energies, 13, 2705. https://doi.org/10.3390/en13112705

Richter, C., \&Dersch, J. (2009).Methods for reducing cooling water consumption in solar thermal power plants. Paper presented at the 15th International solarPACES Symposium, 15-17 September, 2009, Berlin, Germany. [Online] Available:

https://www.researchgate.net/publication/224990715_Methods_for_Reducing_Cooling_Wate r_Consumption_in_Solar_Thermal_Power_Plants

Rodriguez, D.J., Delgado, A., De Laquil, P., \&Sohns, A. (2013, February 26). Thirsty Energy, Water Partnership Program, World Bank.[Online] Available:

https://openknowledge.worldbank.org/handle/10986/16536

Shen, Y., Linville, J.L., Urgun-Demirtas, M., \&Mintz, M.M. (2015). An overview of biogas production and utilization at full scale wastewater treatment plants in the United States: Challenges and opportunities towards energy-neutral WWTPs. Renewable and Sustainable Energy Reviews, 50, 346-362. https://doi.org/10.1016/j.rser.2015.04.129

Shinde, V.B., \&Wandre, S.S. (2015). Solar photovoltaic water pumping system for irrigation: A review. African Journal of Agricultural Research, 10(22), 2267-2273. https://doi.org/10.1016/j.rser.2015.04.129

Solam, K., \&Cerda, E. (2017). The impact of climate change on the generation of hydroelectric power - A case study in Southern Spain.Energies, 10, 1343.

https://doi.org/10.3390/en10091343

Spang, E.S., Moomaw, W.R., Gallagher, K.S., Kirshen, P.H., \& Marks, D.H. (2014). The water consumption of energy production: an international comparison. Environmental Research Letters, 9, 105002. https://doi.org/10.1088/1748-9326/9/10/105002

Tan, C., \&Zhi, Q. (2016). The energy water nexus: A literature review of the dependence of energy on water. Energy Procedia, 88, 277-284. https://doi.org/10.1016/j.egypro.2016.06.154

Tsagarakis, K.P., Dialynas, G.E., \&Angelakis, A.N. (2004). Water resources management in 


\section{Macrothink}

Environmental Management and Sustainable Development

ISSN 2164-7682

Crete (Greece) including water recycling and reuse and proposed quality criteria. Agricultural Water Management, 66, 35-47. https://doi.org/10.1016/j.agwat.2003.09.004

Tzanakakis, V.A., Angelakis, A.N., Paranychiakis, N.V., Dialynas, Y.G., \&Tchobanoglous, G. (2020). Challenges and opportunities for sustainable management of water resources in the island of Crete, Greece.Water, 12, 1538. https://doi.org/10.3390/w12061538

Vourdoubas, J. (2018). Creation of zero carbon emissions wastewater treatment plants - A case study in Crete. Greece.Energy and Environment Research, 8(1), 64-72.

https://doi.org/10.5539/eer.v8n1p64

Vourdoubas, J. (2020). Use of renewable energy sources for energy generation in rural areas in the island of Crete, Greece.European Journal of Environment and Earth Sciences, 1(6), 1-7. https://doi.org/10.24018/ejgeo.2020.1.6.88

Wang, R. (2017, February 24). Water-energy nexus: A critical review paper, Ph.D. Thesis, Yale school of Forestry and Environmental Studies. [Online] Available:

https://hixon.yale.edu/sites/default/files/files/fellows/paper/wang_ranran_2011_report.pdf

Zoulias, E., Varkaraki, E., Lymberopoulos, N., Christodoulou, Ch.N., \&Karagiorgis, G.N. (2004, February 24). A review on water electrolysis. [Online] Available:

http://www.cres.gr/kape/publications/papers/dimosieyseis/ydrogen/A\%20REVIEW\%20ON\% 20WATER\%20ELECTROLYSIS.pdf

\section{Copyright Disclaimer}

Copyright for this article is retained by the author(s), with first publication rights granted to the journal.

This is an open-access article distributed under the terms and conditions of the Creative Commons Attribution license (http://creativecommons.org/licenses/by/4.0/). 